\title{
Vitamin D status of 51-75-year-old Irish women: its determinants and impact on biochemical indices of bone turnover
}

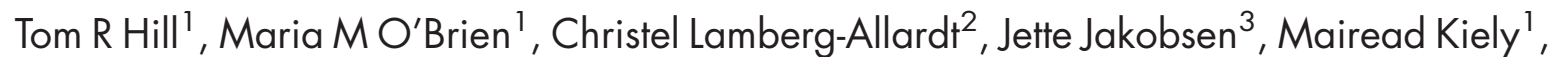 \\ Albert Flynn ${ }^{1}$ and Kevin D Cashman ${ }^{1,4, *}$ \\ ${ }^{1}$ Department of Food and Nutritional Sciences, University College, Cork, Ireland: ${ }^{2}$ Calcium Research Unit, \\ Department of Applied Chemistry and Microbiology, University of Helsinki, Helsinki, Finland: ${ }^{3}$ Danish Institute for \\ Food and Veterinary Research, Söborg, Denmark: ${ }^{4}$ Department of Medicine, University College, Cork, Ireland
}

Submitted 15 February 2005: Accepted 15 June 2005

\begin{abstract}
Objectives: To assess the vitamin D status of Irish postmenopausal women during wintertime, and to examine its relationship with serum parathyroid hormone (PTH) and biochemical markers of bone turnover. In addition, the determinants of wintertime serum 25-hydroxyvitamin D (25OH-D) levels in these women were investigated.

Design: A cross-sectional observational study.

Setting: Cork City, Ireland $\left(52^{\circ} \mathrm{N}\right)$.

Subjects: Ninety-five apparently healthy, free-living postmenopausal women (aged 51-75 years), not taking any medication and free from any condition likely to affect vitamin D status or calcium/bone metabolism.

Results: Forty-eight per cent and 7\% of women had serum 25OH-D levels $<50 \mathrm{nmoll}^{-1}$ and $<25 \mathrm{nmoll}^{-1}$, respectively. $25 \mathrm{OH}-\mathrm{D}$ levels in these women were positively associated with dietary calcium intake $(P=0.0002)$ and use of vitamin $\mathrm{D}$ containing supplements $(P=0.031)$, and negatively associated with cigarette smoking $(P=0.027)$ and body mass index (BMI) $(P=0.030)$. Low serum $25 \mathrm{OH}-\mathrm{D}$ levels $\left(<50 \mathrm{nmoll}^{-1}\right)$ were associated $(P<0.01)$ with elevated serum PTH levels. There were no significant differences in urinary pyridinium crosslinks or serum osteocalcin, biochemical indices of bone turnover, between subjects with serum 25OH-D levels above or below $50 \mathrm{nmoll}^{-1}$.

Conclusion: A high proportion of Irish postmenopausal women had low vitamin D status $\left(<50 \mathrm{nmoll}^{-1}\right)$ during late wintertime, which appeared to lead to elevated levels of serum PTH but not of bone turnover markers. Use of regular low-dose supplemental vitamin $\mathrm{D}$, meeting daily calcium recommendations, cessation of smoking and maintaining BMI in the normal range are important factors that could help maintain adequate vitamin D levels during wintertime in these women.
\end{abstract}

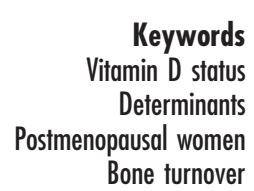

In humans, vitamin $\mathrm{D}$ is obtained primarily through cutaneous biosynthesis in the presence of UV-B sunlight, but also from the diet ${ }^{1}$. Consequently, season is a major determinant of vitamin D status ${ }^{2}$. Vitamin D status is highest in Northern European populations around late summer (August-September) and lowest around late winter/early spring (February-March) ${ }^{3-5}$. In Northern Europe (latitude $40-60^{\circ} \mathrm{N}$ ), including Ireland (latitude $51-55^{\circ} \mathrm{N}$ ), sunlight is too weak during the winter months (October/November to February/March) to stimulate cutaneous vitamin D synthesis ${ }^{6,7}$. This creates an increased reliance on dietary sources during these winter months to help maintain adequate vitamin D status. However, the usual dietary vitamin D intake in Europe is not sufficient to maintain adequate vitamin D status, especially during wintertime ${ }^{4,8}$.

In Ireland, a recent analysis of the North/South Ireland Food Consumption Survey for vitamin intakes estimated that the mean daily intake of vitamin D was $4.2 \mu \mathrm{g}$ in adult men and women (aged 18-64 years) from all sources, including vitamin D-containing supplements 9 . These data show that a considerable proportion of Irish adults have very low dietary intakes of vitamin $\mathrm{D}$ and are largely dependent on sunlight to maintain adequate vitamin D status. Recent data also show that $36-53 \%$ of a group of 51-69-year-old Irish women had low (or some degree of deficient) vitamin D status (defined ${ }^{10,11}$ as serum 25hydroxyvitamin D (25OH-D) levels below $50 \mathrm{nmoll}^{-1}$ ) during wintertime ${ }^{12}$. Furthermore, there was an inverse relationship between serum $25 \mathrm{OH}-\mathrm{D}$ and parathyroid hormone (PTH) in these postmenopausal women ${ }^{12}$. According to Lips ${ }^{11}$, mild vitamin D deficiency (serum 25OH-D levels between 25 and $50 \mathrm{nmoll}^{-1}$ ) can increase serum PTH by up to $15 \%$. However, it is not clear whether this increase should be considered physiological or 
pathological. For example, such an increase may or may not lead to an increased rate of bone turnover ${ }^{11}$. Furthermore, others suggest that serum 25OH-D levels in adults need to be of the order of greater than $78-110 \mathrm{nmoll}^{-1}$ to maintain PTH levels in the normal range and promote intestinal calcium absorption ${ }^{13-19}$. Indeed, some studies have reported a continuous decline in PTH with increasing 25OH-D, and no plateau ${ }^{20,21}$. This among other reasons has contributed to the lack of an international consensus on cut-off levels for vitamin D deficiency/insufficiency ${ }^{16}$, with estimates ${ }^{13-16}$ ranging from $<20$ to $<110$ nmoll $^{-1}$.

In our previous study of seasonal variation in vitamin $\mathrm{D}$ status of Irish postmenopausal women, we found that wintertime serum 25OH-D status was markedly influenced by vitamin D-containing supplement use, but not by body mass index $(\mathrm{BMI})^{12}$. In addition to sunlight and dietary vitamin $\mathrm{D}$ intake, other physiological and behavioural factors have been proposed as determinants of serum 25OH-D levels. These include age ${ }^{22}$, gender $^{23}, \operatorname{race}^{24,25}$, $\mathrm{BMI}^{26,27}$ and smoking ${ }^{28}$. Knowledge of these determinants of vitamin D status, especially during wintertime, is of importance for the development of strategies for prevention of suboptimal vitamin D status.

Therefore, the objectives of the present study were to assess vitamin D status of Irish postmenopausal women (aged 51-75 years) during wintertime, and to examine its relationship with serum PTH and biochemical markers of bone turnover. In addition, determinants of wintertime serum $25 \mathrm{OH}-\mathrm{D}$ levels in these women were investigated.

\section{Subjects and methods}

\section{Subjects}

A convenience sample of 101 apparently healthy, freeliving adult women of white Caucasian extraction (mean age 64.1 years, range 51.0-75.6 years) was recruited by leaflet or direct contact from the Cork region $\left(\sim 52^{\circ} \mathrm{N}\right)$.
None of the subjects was suffering from any condition likely to affect vitamin D status or calcium/bone metabolism. Women were excluded if they were taking medicines likely to affect vitamin D status or calcium/bone metabolism (such as active vitamin D metabolites, calcitonin, PTH, anticonvulsants, steroid hormones, bisphosphonates). Six of the women were taking very high levels of supplemental vitamin D (58-68 $\left.\mu \mathrm{g} \mathrm{day}^{-1}\right)$, which is not reflective of levels in vitamin D-containing supplements used by women, aged 50 years and older, in the general Irish population ${ }^{29}$, as well as being higher than the Tolerable Upper Intake Level $\left(50 \mu \mathrm{g} \mathrm{day}^{-1}\right)^{30}$. Therefore, these women were excluded from further analysis. The mean age, height, weight, BMI, dietary calcium and vitamin $\mathrm{D}$ intake of the women included in the study ( $n=95$ ), as well as the number of smokers, sun-likers and those who took a sun holiday, are provided in Table 1.

\section{Etbical considerations}

Before participation in this study, all subjects signed an informed consent document approved by the Clinical Research Ethics Committee of the Cork Teaching Hospitals.

\section{Design}

This study was a cross-sectional observational study of vitamin D status and its relationship with serum PTH and biochemical markers of bone turnover in postmenopausal Irish women (51-75 years of age) during late wintertime. Each participant was invited to provide a fasting morning blood and urine sample at the University during February/March 2002. After an overnight fast, a blood sample $(20 \mathrm{ml})$ was taken between 08.30 and 10.30 hours. Anthropometric measurements (weight and height) were taken. Habitual food intake was assessed by a 14-day diet history, which consisted of a one-to-one interview detailing usual food and drink intakes in a typical 14-day

Table 1 Physical, dietary and lifestyle characteristics of the entire group of apparently healthy 51-75-year-old Irish women $(n=95)$ and stratified by vitamin D-containing supplement use

\begin{tabular}{|c|c|c|c|c|c|c|}
\hline & \multicolumn{2}{|c|}{ All women $(n=95)$} & \multicolumn{2}{|c|}{$\begin{array}{c}\text { Vitamin D } \\
\text { supplement } \\
\text { non-user }(n=53)\end{array}$} & \multicolumn{2}{|c|}{$\begin{array}{c}\text { Vitamin D } \\
\text { supplement } \\
\text { user }(n=42)\end{array}$} \\
\hline & Mean & SD & Mean & SD & Mean & SD \\
\hline Age (years) & 64.3 & 7.1 & 65.2 & 7.3 & 63.1 & 6.8 \\
\hline Height (m) & 1.60 & 0.06 & 1.59 & 0.06 & 1.61 & 0.05 \\
\hline Weight $(\mathrm{kg})$ & 68.8 & 12.1 & $72.2^{*}$ & 11.7 & 64.6 & 11.2 \\
\hline Body mass index $\left(\mathrm{kg} \mathrm{m}^{-2}\right)$ & 26.9 & 4.8 & $28.5^{\star}$ & 4.6 & 24.9 & 4.3 \\
\hline Dietary vitamin $D$ intake $\left(\mu \mathrm{g} \mathrm{day}^{-1}\right) \dagger$ & 2.97 & 1.86 & $2.5^{\star}$ & 1.39 & 3.54 & 2.22 \\
\hline Calcium intake $\left(\mathrm{mg} \mathrm{day}^{-1}\right)$ & 1027 & 423 & 951 & 441 & 1116 & 381 \\
\hline Number of smokers/non-smokers & $10 / 85$ & - & $3 / 50$ & - & $7 / 35$ & - \\
\hline Number of sun avoiders/likers & $44 / 51$ & - & $21 / 32$ & - & $13 / 29$ & - \\
\hline Number taking a sun holiday & 7 & - & 3 & - & 4 & - \\
\hline
\end{tabular}

SD - standard deviation.

${ }^{*}$ Mean value significantly different from that of vitamin D supplement user: $P<0.05$.

$\dagger$ Excluding vitamin D from supplements.

$\ddagger$ During previous 3 months prior to blood sampling 
period. Food intakes were quantified using a photographic food atlas of food portion sizes ${ }^{31}$. A general health and lifestyle questionnaire was also administered to each participant during the visit, which provided information on medical history, use of hormone replacement therapy, visits to hospital, fracture history and smoking history. The questionnaire also detailed sun habits, sun holidays and the use of sun-beds, medicines and nutritional supplements.

\section{Collection and preparation of samples}

Blood was collected by venepuncture into a Vacutainer tube with no additive and processed to serum, which was immediately stored at $-80^{\circ} \mathrm{C}$ until required for analysis. Subjects were supplied with suitable collection containers for urine samples and asked to collect first morning void urine samples. Portions of urine were stored at $-20^{\circ} \mathrm{C}$ from the morning of collection until required for analysis.

\section{Experimental techniques}

\section{Serum intact PTH}

Intact PTH levels were measured in serum using an enzyme-linked immunosorbent assay (ELISA) (OCTEIA ${ }^{\circledR}$ Intact parathyroid hormone; Immuno Diagnostic Systems, Ltd, Boldon, UK). The intra- and inter- assay coefficient of variation (CV) was $3.4 \%$ and $3.8 \%$, respectively. Based on the manufacturer's information the suggested normal range for PTH is $0.8-3.9 \mathrm{pmoll}^{-1}$, while values between 4.1 and $29.0 \mathrm{pmoll}^{-1}$ are suggestive of primary hyperparathyroidism.

\section{Serum 25OH-D}

$25 \mathrm{OH}-\mathrm{D}$ levels were measured in serum samples using either a recently developed ELISA (OCTEIA ${ }^{\circledR} 25$-Hydroxy Vitamin D; Immuno Diagnostic Systems, Ltd) for women aged 51-69 years or a method based on high-performance liquid chromatography (HPLC) for women aged 70-75 years. For the HPLC-based method, which was performed by the Danish Institute for Food and Veterinary Research, serum proteins were precipitated with ethanol and deproteinised serum was subsequently applied to an MFC18 solid-phase extraction column (Isolute ${ }^{\circledR}$; International Sorbent Technology, Mid Glamorgan, UK) for elution of the $25 \mathrm{OH}-\mathrm{D}$ fraction with ethyl acetate-nheptane. The extracted 25OH-D was injected onto an HPLC system (Waters, Milford, MA, USA) equipped with a 600 controller and pump, a refrigerated $717_{\text {PLus Auto- }}$ sampler, a 996 Diode Array Detector (set at 220-320 nm) for detection and a 2487 Absorbance Detector (set at $265 \mathrm{~nm}$ ) for quantification. The HPLC column used for separation was a cyano (Luna; Phenomenex, Torrance, CA, USA) in which 25-hydroxyvitamin $\mathrm{D}_{2}\left(25 \mathrm{OH}-\mathrm{D}_{2}\right)$ and 25-hydroxyvitamin $\mathrm{D}_{3}\left(25 \mathrm{OH}-\mathrm{D}_{3}\right)$ were eluted separately with 2-propanol-n-heptane. However, none of the samples contained $25 \mathrm{OH}-\mathrm{D}_{2}$. The inter-assay $\mathrm{CV}$ was
6.3\% and the intra-assay CV was 4.3\%. The intra- and interassay CV for the ELISA method (used in University College Cork) was 5.9\% and 6.6\%, respectively. The quality and accuracy of the serum 25OH-D analysis in both laboratories was assured on an ongoing basis by participation in the Vitamin D External Quality Assessment Scheme (DEQAS; Charing Cross Hospital, London, UK). Thirty-three women had their serum 25OH-D levels analysed by the HPLC assay (of whom 21 and 12 were supplement users and non-users, respectively), while the remaining 62 had their serum $25 \mathrm{OH}-\mathrm{D}$ levels analysed by the ELISA assay (of whom 32 and 30 were supplement users and non-users, respectively). There was a very high correlation in reported vitamin D values for DEQAS samples between the two laboratories (ELISA $=1.2781 \times$ HPLC $-3.3218 ; \quad r=0.96 ; \quad P<0.0001$ ), allowing us to combine data from both measurement methods after correction.

There is no international consensus on cut-off levels for vitamin D deficiency/insufficiency ${ }^{16}$. Therefore, for illustrative and comparative purposes in the present study, two suggested sets of serum $25 \mathrm{OH}-\mathrm{D}$ cut-off values for defining vitamin D status were used. These include the definitions of vitamin D status suggested by Heaney and Weaver $^{32}\left(<80 \mathrm{nmoll}^{-1}\right.$, insufficient; $>80 \mathrm{nmoll}^{-1}$, sufficient $)$ and $\operatorname{Lips}^{10,11}\left(>50 \mathrm{nmoll}^{-1}\right.$, replete; 25$50 \mathrm{nmoll}^{-1}$, mildly deficient; $12.5-25 \mathrm{nmoll}^{-1}$; moderately deficient; $<12.5 \mathrm{nmoll}^{-1}$, severely deficient).

\section{Serum osteocalcin}

Osteocalcin levels were measured in serum samples using an ELISA (Metra ${ }^{\mathrm{TM}}$ Osteocalcin EIA Kit; Quidel Corporation, Santa Clara, CA, USA). The intra- and inter- assay CV was $6.0 \%$ and $7.6 \%$, respectively.

\section{Urinary creatinine}

Creatinine was determined in urine samples using a diagnostic kit $\left(\right.$ Metra $^{\mathrm{TM}}$ Creatinine Assay Kit, catalogue no. 8009; Quidel Corporation). The intra- and inter- assay CV was $1.6 \%$ and $3.3 \%$, respectively.

\section{Urinary pyridinoline and deoxypridinoline}

Samples were analysed in duplicate using an automated analysis system (Gilson ASPEC (Automated Sample Preparation with Extraction Columns); Gilson SA, Villiers-le-Bel, France). Extracted samples were linked to a gradient HPLC system comprising a Gilson 321 pump and a Shimadzu RF-10AXL fluorescence detector (Shimadzu Scientific Instruments Inc., Columbia, MD, USA). In brief, portions of pooled urine $(250 \mu \mathrm{l})$ were first hydrolysed with an equal volume of $12 \mathrm{M} \mathrm{HCl}$ at $107^{\circ} \mathrm{C}$ for 18h. The crosslinks from urine hydrolysates were then extracted with cellulose partition chromatography, with the use of an internal standard (acetylated pyridinoline (Pyr); MetraBiosystems Ltd, Wheatley, UK) ${ }^{33}$. The acetylated Pyr was used in accordance with the method described by 
Calabresi et al. ${ }^{34}$ and Robins et al. ${ }^{35}$. The crosslink contents of urine samples were quantified by external standardisation using a commercially available Pyr-deoxypyridinoline (Dpyr) HPLC calibrator (MetraBiosystems Ltd). The intra-assay CV for Pyr and Dpyr, measured as the variation between 10 chromatograms obtained between column regenerations as described by Colwell et al. ${ }^{36}$, was 5\% and $3 \%$, respectively. The inter-assay CV for Pyr and Dpyr was $9 \%$ and $11 \%$, respectively.

\section{Statistical analysis}

Data are presented as mean and standard deviation (SD). Data for all variables were normally distributed and allowed for parametric tests of significance. Differences in physical variables, dietary and lifestyle factors and biochemical indices of bone turnover between vitamin $\mathrm{D}$ supplement users and non-users were analysed using unpaired Student $t$-tests. Differences in biochemical indices according to serum 25OH-D cut-off levels for defining vitamin D adequacy/inadequacy and sufficiency/insufficiency were analysed using unpaired Student $t$ tests. Multiple regression analysis was performed to identify independent predictors of serum 25OH-D. The following categorical variables were included: vitamin D supplements (coded as $0=$ no supplements, $1=$ taking supplements regularly), sun habits ('Do you prefer to avoid sun during summer season (avoid sun) or stay in sun during the summer season (prefer sun)?'), taking sun holidays within previous 3 months $(0=$ no, $1=$ yes $)$, smoking habits ('Are you a smoker or non-smoker?'). The following continuous numerical variables were included: age (years), BMI $\left(\mathrm{kg} \mathrm{m}^{-2}\right)$, habitual vitamin $\mathrm{D}$ intake $\left(\mu \mathrm{gday}^{-1}\right)$ and calcium intake $\left(\mathrm{mgday}^{-1}\right)$. Linear regression was used to investigate the association between serum $25 \mathrm{OH}-\mathrm{D}$ and PTH. $P$-values $<0.05$ were considered statistically significant.

\section{Results}

\section{Physical, dietary and lifestyle characteristics}

The age, weight, height, BMI, calcium intake, habitual dietary vitamin D, smoking habits and sun habits of the women $(n=95)$ are shown in Table 1 . Stratification of women into users $(n=42)$ and non-users $(n=53)$ of vitamin D-containing supplements showed that there was no significant difference in mean age or height, or in smoking habits, sun habits or number taking sun holidays, between the two groups (Table 1). Supplement non-users were significantly $(P<0.01)$ heavier and had a higher $(P<0.01)$ BMI than supplement users (Table 1$)$. Supplement non-users had significantly $(P<0.05)$ lower dietary vitamin D intakes than supplement users (Table 1).

\section{Dietary intake of vitamin $D$ and calcium}

Mean (SD) habitual daily intake of vitamin D and calcium (from food and supplements) was 5.4 (7.4) $\mu \mathrm{g}$ and 1027
(423) $\mathrm{mg}$, respectively, in 51-75-year-old women. In addition, the mean, $\mathrm{SD}$, median and range of the vitamin $\mathrm{D}$ content of supplements, as used by the women $(n=42)$, was $6,4.9,5$ and $2.5-20 \mu \mathrm{g}$, respectively.

\section{Vitamin D status and prevalence of low vitamin $D$ status and vitamin $D$ insufficiency}

Mean serum 25OH-D concentration for the entire group of Irish postmenopausal women is shown in Table 2. Using the serum $25 \mathrm{OH}-\mathrm{D}$ cut-offs levels for defining vitamin D status suggested by Lips ${ }^{10,11}$ revealed that none of the women had severe vitamin D deficiency $\left(<12.5 \mathrm{nmoll}^{-1}\right)$, $7 \%$ had moderate vitamin D deficiency $\left(12.5-25 \mathrm{nmoll}^{-1}\right.$ ), $41 \%$ had mild vitamin D deficiency $\left(25-50 \mathrm{nmoll}^{-1}\right)$ and $52 \%$ were vitamin D-replete $\left(>50 \mathrm{nmoll}^{-1}\right)$. Using the alternative serum $25 \mathrm{OH}$-D cut-off value of greater or less than $80 \mathrm{nmoll}^{-1}$ to define vitamin D sufficiency and insufficiency respectively, as suggested by Heaney and Weaver ${ }^{32}, 21 \%$ of women were vitamin D-sufficient and 79\% of women were vitamin D-insufficient.

Table 2 Serum and urinary indices of vitamin $D$ status and bone turnover in the entire group $(n=95)$ of $51-75$-year-old Irish postmenopausal women and stratified by vitamin D-containing supplement use during February/March 2002

\begin{tabular}{|c|c|c|c|}
\hline & All women & $\begin{array}{c}\text { Supplement } \\
\text { non-user }\end{array}$ & $\begin{array}{c}\text { Supplement } \\
\text { user }\end{array}$ \\
\hline \multicolumn{4}{|c|}{$\begin{array}{l}\text { Serum } \\
250 \mathrm{O}-\mathrm{D}\left(\mathrm{nmoll}^{-1}\right)\end{array}$} \\
\hline$n$ & 95 & 53 & 42 \\
\hline Mean & 57.2 & $48.3^{*}$ & 68.4 \\
\hline SD & 26.9 & 21.6 & 28.9 \\
\hline Median & 52.3 & 45.5 & 63.9 \\
\hline Range & $17.0-140.0$ & $17.0-110.6$ & $26.7-140.0$ \\
\hline \multicolumn{4}{|c|}{ PTH (pmoll $\left.{ }^{-1}\right)$} \\
\hline$n$ & 94 & 52 & 42 \\
\hline Mean & 2.83 & 2.89 & 2.75 \\
\hline SD & 1.25 & 1.31 & 1.20 \\
\hline Median & 2.83 & 2.88 & 2.82 \\
\hline Range & $0.38-7.11$ & $0.38-7.11$ & $0.42-6.14$ \\
\hline \multicolumn{4}{|c|}{ Osteocalcin $\left(\mathrm{ng} \mathrm{ml}^{-1}\right)$} \\
\hline$n$ & 90 & 51 & 39 \\
\hline Mean & 16.8 & 18.2 & 15.0 \\
\hline SD & 10.6 & 11.0 & 9.9 \\
\hline Median & 13.3 & 13.4 & 12.7 \\
\hline Range & $1.7-56.4$ & $4.9-56.4$ & $1.7-54.2$ \\
\hline \multicolumn{4}{|c|}{ Urine } \\
\hline \multicolumn{4}{|c|}{ Pyr (nmol mmol $\left.{ }^{-1} \mathrm{Cr}\right)$} \\
\hline$n$ & 87 & 52 & 35 \\
\hline Mean & 21.6 & 21.3 & 22.1 \\
\hline SD & 12.1 & 12.8 & 11.1 \\
\hline Median & 21.3 & 20.8 & 21.4 \\
\hline Range & $0.8-51.2$ & $0.75-46.7$ & $4.9-51.2$ \\
\hline \multicolumn{4}{|c|}{ Dpyr (nmol mmol $\left.{ }^{-1} \mathrm{Cr}\right)$} \\
\hline$n$ & 87 & 52 & 35 \\
\hline Mean & 7.50 & 7.26 & 7.85 \\
\hline SD & 4.12 & 4.21 & 4.01 \\
\hline Median & 6.83 & 6.44 & 8.08 \\
\hline Range & $0.22-20.18$ & $0.22-20.18$ & $2.14-18.95$ \\
\hline
\end{tabular}

25OH-D - 25-hydroxyvitamin D; SD - standard deviation; PTH - parathyroid hormone; Pyr - pyridinoline; $\mathrm{Cr}$ - creatinine; Dpyr - deoxypyridinoline. ${ }^{*}$ Mean value significantly different from that of vitamin D supplement user: $P=0.0003$. 


\section{Determinants of serum 25OH-D levels}

To investigate the determinants of serum 25OH-D levels in the 51-75-year-old women multiple regression analysis was performed, and the outcome is presented in Table 3. Total calcium intake $(P=0.0002)$ and use of vitamin Dcontaining supplements $(P=0.031)$ were positively associated with serum 250H-D levels, while smoking $(P=0.027)$ and BMI $(P=0.030)$ were negatively associated with serum $25 \mathrm{OH}-\mathrm{D}$ levels (Table 3 ). There was no significant association between age, avoidance of sunshine during summertime, taking sun holidays or vitamin D intake and serum 25OH-D levels (Table 3). Approximately $37 \%$ of the total variation in wintertime serum 25OH-D concentration was explained by this model.

\section{Biochemical indices of vitamin $D$ status and bone turnover}

Serum and urinary indices of vitamin D status and bone turnover in Irish postmenopausal women during late winter 2002, stratified by vitamin D-containing supplement use, are shown in Table 2. Mean serum 25OH-D levels of vitamin D-containing supplement users was significantly $(P=0.0003)$ higher than that of non-users (Table 2). There were no significant differences in serum PTH or osteocalcin, or urinary Pyr and Dpyr, between supplement users and non-users. After adjustment for BMI and habitual dietary vitamin $\mathrm{D}$ intake, serum 25OH-D remained significantly higher $(P<0.01)$ in supplement users than non-users. This significant difference between groups was also evident $(P<0.05)$ even after adjustment for all factors (BMI, age, smoking habits, sun habits, calcium intake, vitamin D intake and sun holidays). There were no differences in serum PTH or osteocalcin, or urinary Pyr and Dpyr, between the two groups (Table 2), even after adjustment for differences in BMI and dietary vitamin D.

\section{Influence of vitamin $D$ deficiency/insufficiency on biochemical indices of vitamin $D$ status and bone turnover}

Mean serum PTH $(P=0.007)$ was significantly lower in women with serum 250H-D levels $>50 \mathrm{nmoll}^{-1}$ compared with those with levels $<50 \mathrm{nmoll}^{-1}$ (Table 4).
There were no significant differences in serum osteocalcin or urinary Pyr or Dpyr between the two groups. Using the alternative suggested cut-off values of serum $25 \mathrm{OH}-\mathrm{D}$, serum PTH $(P=0.033)$ was significantly lower in women with serum $25 \mathrm{OH}-\mathrm{D}$ levels $>80 \mathrm{nmoll}^{-1}$ than in women with serum $25 \mathrm{OH}-\mathrm{D}$ levels $<80 \mathrm{nmol}^{-1}$, while there were no significant differences in serum osteocalcin or urinary Pyr or Dpyr between the two groups (Table 4).

\section{Association between serum $25 \mathrm{OH}-\mathrm{D}$ concentration and biochemical indices}

Using linear regression, there was a significant inverse relationship between serum 25OH-D and serum PTH $(r=-0.241 ; P=0.014 ; n=94)$. There were no significant correlations between serum 25OH-D and other biochemical indices (data not shown).

\section{Discussion}

In the present study, the mean habitual daily vitamin D intake of Irish postmenopausal women (51-75 years old) was $5.4 \mu \mathrm{g}$ from all sources (i.e. food and nutritional supplements). This intake estimate is in line with that recently reported by us for a nationally representative sample of Irish adult women (50-64 years old) $(5.1 \mu \mathrm{g}$ from food and supplements $)^{9}$.

About half $(\sim 48 \%)$ of the 51-75-year-old Irish postmenopausal women participating in the present study had low vitamin D status (ranging from mild (41\%) to moderate (7\%) vitamin D deficiency, defined by serum $25 \mathrm{OH}-\mathrm{D}$ cut-off values as suggested by Lips $^{10,11}$ ) during late winter. This finding confirms previous reports of a very high prevalence of low vitamin D status among healthy free-living elderly Irish adults during late winter $^{12,37-40}$. Furthermore, the proportion of women with low vitamin D status (serum 25OH-D levels $<50 \mathrm{nmoll}^{-1}$ ) in the present study is in line with estimates of the prevalence of low vitamin D status among healthy free-living elderly European women ${ }^{8,10,41}$.

As mentioned already, there is no international consensus on cut-off levels for vitamin D deficiency/insufficiency $^{16}$. While there are several reasons for this uncertainty $^{42}$, it is further complicated by methodological

Table 3 Multiple linear regression analysis with serum 25-hydroxyvitamin D in 51-75-yearold women $(n=95)$ as the dependent variable

\begin{tabular}{lccrr}
\hline & $B$ & $95 \% \mathrm{Cl}$ & \multicolumn{1}{c}{$\beta$} & $P$-value \\
\hline Taking vitamin D supplements & 13.216 & $1.214,25.219$ & 0.248 & 0.031 \\
Vitamin D intake & -2.141 & $-5.098,0.816$ & -0.149 & 0.153 \\
Calcium intake & 0.024 & $0.012,0.037$ & 0.388 & $<0.001$ \\
Sun habits, avoid sun & -4.566 & $-15.231,6.099$ & -0.081 & 0.396 \\
Smoking, smokers & -18.845 & $-35.460,-2.230$ & -0.223 & 0.027 \\
Body mass index & -1.420 & $-2.697,-0.142$ & -0.237 & 0.030 \\
Age & -0.058 & $-0.790,-0.674$ & -0.015 & 0.875 \\
Sun holidays, not taking & -9.127 & $-28.576,10.321$ & -0.090 & 0.353 \\
\hline
\end{tabular}

$B$ - coefficient; $95 \% \mathrm{Cl}-95 \%$ confidence interval for $B ; \beta$ - standardised coefficient. 
Table 4 Biochemical indices of vitamin D status and bone turnover in 51-75-year-old postmenopausal women, categorised according to various suggested serum 25 -hydroxyvitamin $\mathrm{D}(25 \mathrm{OH}-\mathrm{D})$ cut-offs for defining vitamin D deficiency/insufficiency

\begin{tabular}{|c|c|c|c|c|c|c|}
\hline & \multicolumn{6}{|c|}{ Serum $25 \mathrm{OH}-\mathrm{D}$ cut-offs $\left(\mathrm{nmoll}{ }^{-1}\right)$} \\
\hline & \multicolumn{2}{|c|}{$\left(\operatorname{Lips}^{11}\right)$} & \multirow[b]{2}{*}{$P$-value } & \multicolumn{2}{|c|}{$\begin{array}{c}\text { (Heaney } \\
\text { and Weaver }{ }^{32} \text { ) }\end{array}$} & \multirow[b]{2}{*}{$P$-value } \\
\hline & $<50$ & $>50$ & & $<80$ & $>80$ & \\
\hline$\underset{(n)}{250 \mathrm{O}-\mathrm{D}}\left(\mathrm{nmoll}^{-1}\right)$ & $\begin{array}{l}35.5 \\
46\end{array}$ & $\begin{array}{l}77.5 \\
49\end{array}$ & $<0.0001$ & $\begin{array}{l}46.3 \\
75\end{array}$ & $\begin{array}{l}97.9 \\
20\end{array}$ & $<0.0001$ \\
\hline PTH $\left(\right.$ pmoll $\left.{ }^{-1}\right)$ & 3.02 & 2.41 & 0.007 & 2.83 & 2.24 & 0.033 \\
\hline $\begin{array}{l}\text { Osteocalcin }\left(\mathrm{ng} \mathrm{ml}^{-1}\right) \\
(n)\end{array}$ & $\begin{array}{l}45 \\
16.6 \\
45\end{array}$ & $\begin{array}{l}49 \\
17.0 \\
45\end{array}$ & 0.839 & $\begin{array}{l}74 \\
17.5 \\
71\end{array}$ & $\begin{array}{l}20 \\
20.0 \\
19\end{array}$ & 0.121 \\
\hline $\begin{array}{l}\operatorname{Pyr}\left(\mathrm{nmol} \mathrm{mmol}^{-1} \mathrm{Cr}\right) \\
(n)\end{array}$ & $\begin{array}{l}22.1 \\
44\end{array}$ & $\begin{array}{l}21.2 \\
43\end{array}$ & 0.729 & $\begin{array}{l}22.1 \\
70\end{array}$ & $\begin{array}{l}19.8 \\
17\end{array}$ & 0.487 \\
\hline $\begin{array}{l}\operatorname{Dpyr}\left(\mathrm{nmol} \mathrm{mmol}{ }^{-1} \mathrm{Cr}\right) \\
(n)\end{array}$ & $\begin{array}{l}8.04 \\
44\end{array}$ & $\begin{array}{l}6.93 \\
43\end{array}$ & 0.209 & $\begin{array}{l}7.69 \\
70\end{array}$ & $\begin{array}{c}6.70 \\
17\end{array}$ & 0.378 \\
\hline
\end{tabular}

PTH - parathyroid hormone; Pyr - pyridinoline; Dpyr - deoxypyridinoline; $\mathrm{Cr}$ - creatinine.

issues surrounding analysis of serum 25OH-D levels. Different methods of analysis can produce different serum 25OH-D levels, as illustrated recently in round-robin analyses of the DEQAS samples ${ }^{43}$. In the present study, the HPLC analytical method produced lower serum 25OH-D levels than those obtained by the ELISA method. Thus, notwithstanding uncertainty about cut-off values, differences arising from analytical methods can cause difficulties in categorising individuals as being vitamin D-deficient/insufficient. This was avoided in the present study by application of a correction factor to account for such differences.

This is the first study, to our knowledge, which has investigated determinants of serum 25OH-D levels among Irish adults. Knowledge of such determinants is important for formulation of strategies and recommendations for preventing wintertime vitamin D deficiency in the population. In the present study, smoking was negatively associated with serum 25OH-D levels in 51-75-year-old Irish women. The effect of smoking on serum 25OH-D levels is unclear. Some studies show a negative association between smoking and serum 25OH-D in young, middleaged and elderly subjects ${ }^{28,41,44,45}$, while others fail to find this association ${ }^{25,46,47}$. Increasing BMI was negatively associated with serum 25OH-D levels in the present study, which is in line with the findings of some $e^{25-27,41,47-49}$, but not all ${ }^{4,46}$ studies.

Ageing has been shown to affect vitamin D synthesis primarily through a reduced capability of skin biosynthesis $^{22,50,51}$. Age was not found to be a determinant of vitamin D status in women in the present study. However, all of the women were apparently healthy, free-living and aged between 51 and 75 years. Similarly, age was not found to be a significant determinant of vitamin D status in our previous study of 51-69-year-old women ${ }^{12}$.

In the present study, as well as in other studies ${ }^{26,47}$, sun exposure from the previous summer was measured indirectly, using a simple questionnaire to assess sun habits and preferences. The multiple regression analysis indicated that avoiding summer sunshine was not associated with wintertime serum 25OH-D levels, which is in line with the findings of Jacques et $a l .{ }^{47}$ but in contrast with the findings of Burnand et al. ${ }^{26}$. It should be pointed out, however, that these questionnaires are crude estimates of sunshine exposure. Use of a more direct method of assessing sunshine exposure, such as ultraviolet dosimetry, may be a more meaningful approach for assessing summer sunshine exposure as a determinant of serum 25OH-D levels ${ }^{52}$.

Vitamin D intake was not associated with wintertime serum 25OH-D levels in postmenopausal women in the present study. These results are in contrast with those of others who have demonstrated a significant positive association between vitamin $\mathrm{D}$ intake and serum $25 \mathrm{OH}-\mathrm{D}$ during winter ${ }^{13,15,20,47,53}$. According to Jacques et al. ${ }^{47}$, vitamin D intake becomes a significant predictor of serum 25OH-D concentration only when intakes are above $\sim 4 \mu \mathrm{g} \mathrm{day}^{-1}$. The median vitamin D intake in the present study was only $3.1 \mu \mathrm{g} \mathrm{day}^{-1}$, and about two-thirds of women had intakes below $4 \mu \mathrm{g} \mathrm{day}^{-1}$. Calcium intake, on the other hand, was positively associated with serum 25OH-D levels in the postmenopausal women in the present study, which is in agreement with the findings of van der Wielen et $a l^{4}$ and Kinyamu et al. ${ }^{53}$.

In the present study, there was a positive association between taking vitamin D-containing supplements and serum 25OH-D levels. Other studies also show a similar association between supplemental vitamin D use and serum $25 \mathrm{OH}-\mathrm{D}^{47,54}$. To further explore the impact of supplemental vitamin D use on serum 25OH-D levels in the postmenopausal women in the present study, the women were stratified by vitamin D-containing supplement use. Vitamin D-containing supplement users had significantly higher serum $25 \mathrm{OH}-\mathrm{D}$ levels $\left(\sim 20 \mathrm{nmoll}^{-1}\right.$ 
higher) than non-supplement users during wintertime, which was not explained by differences in other determinants of vitamin D status between the two groups.

Low vitamin D status, however, may be of little consequence to bone health unless PTH, a potent proresorptive agent, is increased. In the present study, women with serum $25 \mathrm{OH}-\mathrm{D}$ levels $<50 \mathrm{nmoll}^{-1}$ had significantly higher PTH levels (by $\sim 20 \%$ ) than women with serum 25OH-D levels $>50 \mathrm{nmoll}^{1}$. According to Lips ${ }^{11}$, serum PTH begins to increase (by up to $15 \%$ and between 15 and $30 \%$ ) when serum $25 \mathrm{OH}-\mathrm{D}$ levels fall into the range $25-$ $50 \mathrm{nmoll}^{-1}$ and $12.5-25 \mathrm{nmoll}^{-1}$, respectively. However, there is considerable debate as to the point of inflection of PTH (i.e. the level of serum 25OH-D at which serum PTH plateaus) ${ }^{13-15,55}$. For example, Chapuy et al. ${ }^{14}$ suggest that serum $25 \mathrm{OH}-\mathrm{D}$ should be as high as $78 \mathrm{nmol}^{-1}$ to prevent any rise in $\mathrm{PTH}$, while others show no plateau ${ }^{20,21}$. In the present study, women with serum 25OH-D levels $<80 \mathrm{nmoll}^{-1}$ had significantly higher PTH levels (by $\sim 21 \%$ ) than women with serum 25OH-D levels $>80 \mathrm{nmoll}^{-1}$.

Mild vitamin D deficiency may or may not increase the levels of markers of bone turnover ${ }^{11}$. Using the serum 25OH-D cut-offs for defining vitamin D deficiency and insufficiency $\left(<50 \mathrm{nmoll}^{-1}\right.$ (references 10 and 11) and $<80 \mathrm{nmoll}^{-1}$ (reference 32), respectively), which are primarily based on the response of PTH, we were unable to detect any significant differences in serum osteocalcin or urinary Pyr or Dpyr in the 51-75-year-old women, despite $\sim 20 \%$ increases in serum PTH. However, the number of subjects in each group $\left(n=46,<50 \mathrm{nmoll}^{-1}\right.$; $n=49,>50 \mathrm{nmoll}^{-1}$ and $n=75,<80 \mathrm{nmoll}^{-1} ; n=20$, $>80 \mathrm{nmoll}^{-1}$ ) may have limited our ability to detect subtle differences in bone marker levels. To date, there is a limited number of studies which have investigated the relationship between serum $25 \mathrm{OH}-\mathrm{D}$ levels and biochemical indices of bone turnover ${ }^{56-58}$. These studies suggest various serum $25 \mathrm{OH}-\mathrm{D}$ levels to define vitamin $\mathrm{D}$ insufficiency, based on the responses of indices of bone turnover. For example, Sahota et al. ${ }^{56}$ suggest that serum $25 \mathrm{OH}-\mathrm{D}$ levels $<30 \mathrm{nmoll}^{-1}$ are associated with an increase in bone turnover markers. However, Jesudason et al. ${ }^{58}$ and Mezquita-Raya et $a l^{57}$ suggest that higher thresholds $\left(<60 \mathrm{nmoll}^{-1}\right.$ and $<70 \mathrm{nmoll}^{-1}$, respectively) should be used to define vitamin D insufficiency, based on a rise in bone turnover markers. Interestingly, Mezquita-Raya et al. ${ }^{57}$ did not detect any differences in biomarkers of bone turnover between women with serum 25OH-D levels less than or greater than $37.5 \mathrm{nmoll}^{-1}$, but did find a significant difference in bone turnover markers when a higher serum 25OH-D threshold level $\left(<70 \mathrm{nmoll}^{-1}\right)$ was applied.

\section{Conclusion}

A high proportion (48\%) of Irish postmenopausal women had low vitamin D status (serum 25OH-D $<50 \mathrm{nmoll}^{-1}$ ) during late winter. However, low-dose vitamin D supplementation (mean $\sim 6 \mu \mathrm{g} \mathrm{day}^{-1}$ ) was associated with a considerably lower prevalence of low vitamin D status in these women. The low vitamin D status in this study was associated with significantly elevated PTH levels, but had no effect on biochemical indices of bone turnover. Because both low-dose supplemental vitamin D and calcium intake were positively associated with serum 25OH-D levels, postmenopausal women should be encouraged to use regular low-dose supplemental vitamin D during winter as well as meet their daily calcium recommendations, to help counteract the natural wintertime decline in serum 25OH-D levels. In addition, cessation of smoking and maintaining BMI in the normal range are additional factors that could help maintain adequate vitamin D levels during the winter.

\section{References}

1 Parfitt AM, Gallagher JC, Heaney RP, Johnston CC, Neer R, Whedon GD. Vitamin D and bone health in the elderly. American Journal of Clinical Nutrition 1982; 36: 1014-31.

2 Stamp TC, Round JM. Seasonal changes in human plasma levels of 25-hydroxyvitamin D. Nature 1974; 247: 563-5.

3 McKenna MJ. Differences in vitamin D status between countries in young adults and the elderly. American Journal of Clinical Nutrition 1992; 93: 69-77.

4 Van der Wielen RPJ, Lowik MRH, Van Den Berg H, De Groot LCPGM, Haller J, Moreiras O, et al. Serum vitamin D concentrations among elderly people in Europe. Lancet 1995; 346: 207-10.

5 Lips P, Duong T, Oleksik A, Black D, Cummings S, Cox D, et al. A global study of vitamin D status and parathyroid function in postmenopausal women with osteoporosis: baseline data from the multiple outcomes of raloxifene evaluation clinical trial. Journal of Clinical Endocrinology and Metabolism 2001; 86: 1212-21.

6 Webb AR, Kline L, Holick MF. Influence of season and latitude on the cutaneous synthesis of vitamin $\mathrm{D}_{3}$ : exposure to winter sunlight in Boston and Edmonton will not promote vitamin $\mathrm{D}_{3}$ synthesis in human skin. Journal of Clinical Endocrinology and Metabolism 1988; 67: 373-8.

7 Food and Agriculture Organization (FAO)/World Health Organization (WHO). Human Vitamin and Mineral Requirements. Report of the Joint FAO/WHO Expert Consultation, Bangkok, Thailand. Rome: Food and Nutrition Division, FAO, 1998. Also available at http://ftp.fao.org/es/ esn/nutrition

8 Ovesen L, Andersen R, Jakobsen J. Geographical differences in vitamin D status, with particular reference to European countries. Proceedings of the Nutrition Society 2003; 62: $813-21$

9 Hill TR, O’Brien MM, Kiely M, Flynn A, Cashman KD. Vitamin D intakes in 18-64 year-old Irish adults. European Journal of Clinical Nutrition 2004; 58: 1509-17.

10 Lips P. Vitamin D deficiency and secondary hyperparathyroidism in the elderly: consequences for bone loss and fractures and therapeutic implications. Endocrine Reviews 2001; 22: 477-501.

11 Lips P. Which circulating level of 25-hydroxyvitamin D is appropriate? Journal of Steroid Biochemistry and Molecular Biology 2004; 89-90: 611-4.

12 Hill T, Collins A, O'Brien MM, Kiely M, Flynn A, Cashman KD. Vitamin D intake and status in Irish postmenopausal 
women. European Journal of Clinical Nutrition 2005; 59 404-10.

13 Krall EA, Sahyoun N, Tannenbaum S, Dallal GE, DawsonHughes B. Effect of vitamin D intake on seasonal variations in parathyroid hormone secretion in postmenopausal women. New England Journal of Medicine 1989; 321 $1777-83$.

14 Chapuy MC, Preziosi P, Maamer M, Arnaud S, Galan P, Hercberg S, et al. Prevalence of vitamin D insufficiency in an adult normal population. Osteoporosis International 1997; 7: 439-43.

15 Dawson-Hughes B, Harris SS, Dallal GE. Plasma calcidiol, season, and serum parathyroid hormone concentrations in healthy elderly men and women. American Journal of Clinical Nutrition 1997; 65: 67-71.

16 McKenna MJ, Freaney R. Secondary hyperparathyroidism in the elderly: means to defining hypovitaminosis D. Osteoporosis International 1998; 8: S3-6.

17 Heaney RP, Dowell MS, Hale CA, Bendich A. Calcium absorption varies within the reference range for serum 25hydroxyvitamin D. Journal of the American College of Nutrition 2003; 22: 142-6.

18 Zittermann A. Vitamin D in preventive medicine: are we ignoring the evidence? British Journal of Nutrition 2003; 89 $552-72$.

19 Holick MF. Vitamin D: importance in the prevention of cancers, type-1 diabetes, heart disease and osteoporosis. American Journal of Clinical Nutrition 2004; 79: 362-71.

20 Bates CJ, Carter GD, Mishra GD, O'Shea D, Jones J, Prentice A. In a population study, can parathyroid hormone aid the definition of adequate vitamin D status? A study of people aged 65 years and over from the British National Diet and Nutrition Survey. Osteoporosis International 2003; 14 $152-9$.

21 Vieth R, Ladak Y, Walfish PG. Age-related changes in the 25hydroxyvitamin $\mathrm{D}$ versus parathyroid hormone relationship suggest a different reason why older adults require more vitamin D. Journal of Clinical Endocrinology and Metabolism 2003; 88: 185-91.

22 MacLaughlin J, Holick MF. Aging decreases the capacity of human skin to produce vitamin $\mathrm{D}_{3}$. Journal of Clinical Investigation 1985; 76: 1536-8.

23 Sherman SS, Hollis BW, Tobin JD. Vitamin D status and related parameters in a healthy population: the effects of age, sex and season. Journal of Clinical Endocrinology and Metabolism 1990; 71: 405-13.

24 Harris SS, Soteriades E, Coolidge JA-S, Mudgal S, DawsonHughes B. Vitamin D insufficiency and hyperparathyroidism in a low income, multiracial, elderly population. Journal of Clinical Endocrinology and Metabolism 2000; 85: 4125-30.

25 Arunabh S, Pollack S, Yeh J, Aloia JF. Body fat content and 25-hydroxyvitamin D levels in healthy women. Journal of Clinical Endocrinology and Metabolism 2003; 88: 157-61.

26 Burnand B, Sloutskis D, Gianoli F, Cornuz J, Rickenbach M, Paccaud F, et al. Serum 25-hydroxyvitamin D: distribution and determinants in the Swiss population. American Journal of Clinical Nutrition 1992; 56: 537-42.

27 Parikh SJ, Edelman M, Uwaifo GI, Freedman RJ, SemegaJanneh M, Reynolds J, et al. The relationship between obesity and serum 1,25-dihydroxyvitamin D concentrations in healthy adults. Journal of Clinical Endocrinology and Metabolism 2004; 89: 1196-9.

28 Brot C, Jorgensen NR, Sørensen OH. The influence of smoking on vitamin D status and calcium metabolism. European Journal of Clinical Nutrition 1999; 53: 920-6.

29 Kiely M, Flynn A, Harrington KE, Robson PJ, O'Connor N, Hannon EM, et al. The efficacy and safety of nutritional supplement use in a representative sample of adults in the North/South Ireland Food Consumption Survey. Public Health Nutrition 2001; 4: 1089-97.
30 Food and Nutrition Board, Institute of Medicine. Dietary Reference Intakes for Calcium, Phosphorus, Magnesium, Vitamin $D$ and Fluoride. Washington, DC: National Academy Press, 1997.

31 Ministry of Agriculture, Fisheries and Food. Food Portion Sizes. London: The Stationery Office, 1997.

32 Heaney RP, Weaver CM. Calcium and vitamin D. Endocrinology and Metabolism Clinics of North America 2003; 32 181-94.

33 Pratt DA, Daniloff Y, Duncan A, Robins SP. Automated analysis of the pyridinium crosslinks of collagen in tissue and urine using solid-phase extraction and reversed-phase high-performance liquid chromatography. Analytical Biochemistry 1992; 207: 168-75.

34 Calabresi E, Lasagni L, Franceschelli F, Bartolini L, Serio M, Brandi ML. Use of an internal standard to measure pyridinoline and deoxypyridinoline in urine. Clinical Chemistry 1994; 40: 336-7.

35 Robins SP, Stead DA, Duncan A. Precautions in using an internal standard to measure pyridinoline and deoxypyridinoline in urine. Clinical Chemistry 1994; 40: 2322-3.

36 Colwell A, Russell RG, Eastell R. Factors affecting the assay of urinary 3-hydroxypyridinium crosslinks of collagen as markers of bone resorption. European Journal of Clinical Investigation 1993; 23: 341-9.

37 McKenna M, Freaney R, Keating D, Muldowney FP. The prevalence and management of vitamin D deficiency in an acute geriatric unit. Irish Medical Journal 1981; 74: 336-8.

38 McKenna MJ, Freaney R, Meade A, Muldowney FP. Hypovitaminosis D and elevated serum alkaline phosphatase in elderly Irish people. American Journal of Clinical Nutrition 1985; 41: 101-9.

39 Meade A, Moloney M, O'Keeffe D. Prevalence of vitamin D deficiency in the elderly in two rural areas in Ireland. Irish Medical Journal 1986; 79: 359.

40 Freaney R, McBrinn Y, McKenna MJ. Secondary hyperparathyroidism in elderly people: combined effect of renal insufficiency and vitamin D deficiency. American Journal of Clinical Nutrition 1993; 58: 187-91.

41 Andersen R, Mølgaard C, Skivgaard LT, Brot C, Cashman KD, Chabros E, et al. Prevalence of hypovitaminosis D in two risk groups in European countries. European Journal of Clinical Nutrition 2005; 59: 533-41.

42 Dawson-Hughes B, Heaney RP, Holick MF, Lips P, Meunier PJ, Vieth R. Estimates of optimal vitamin D status. Osteoporosis International 2005; 16: 713-6.

43 Carter GD, Carter R, Jones J, Berry J. How accurate are assays for 25-hydroxyvitamin D? Data from the international vitamin D external quality assessment scheme. Clinical Chemistry 2004; 50: 2195-7.

44 Lamberg-Allardt CJ, Outila TA, Kärkkäinen MU, Rita HJ, Valsta LM. Vitamin D deficiency and bone health in healthy adults in Finland: could this be a concern in other parts of Europe? Journal of Bone Mineral Research 2001; 16 2066-73.

45 Ilich JZ, Brownbill RA, Tamborini L, Crncevic-Orlic Z. To drink or not to drink: how are alcohol, caffeine and past smoking related to bone mineral density in elderly women? Journal of the American College of Nutrition 2002; 21: 536-44.

46 Scragg R, Holdaway I, Jackson R, Lim T. Plasma 25hydroxyvitamin $\mathrm{D}_{3}$ and its relation to physical activity and other heart disease risk factors in the general population. Annals of Epidemiology 1992; 2: 697-703.

47 Jacques PF, Felson DT, Tucker KL, Mahnken B, Wilson PWF, Rosenberg IH, et al. Plasma 25-hydroxyvitamin D and its determinants in an elderly population sample. American Journal of Clinical Nutrition 1997; 66: 929-36.

48 Liel Y, Shany S, Schwartz B. Interaction between estrogen and vitamin D-endocrine system: a potential addition to the 
unitary model of osteoporosis. Journal of Bone Mineral Research 1998; 13: 1954-5.

49 Wortsman J, Matsuoka LY, Chen TC, Lu Z, Holick MF. Decreased bioavailability of vitamin D in obesity. American Journal of Clinical Nutrition 2000; 72: 690-3.

50 Need AG, Morris HA, Horowitz M, Nordin C. Effects of skin thickness, age, body fat, and sunlight on serum 25hydroxyvitamin D. American Journal of Clinical Nutrition 1993; 58: $882-5$.

51 Holick MF. Environmental factors that influence the cutaneous production of vitamin D. American Journal of Clinical Nutrition 1995; 61: 638S-45S.

52 Terenetskaya I. Two methods for direct assessment of the vitamin D synthetic capacity of sunlight and artificial UV sources. Journal of Steroid Biochemistry and Molecular Biology 2004; 89-90: 623-6.

53 Kinyamu HK, Gallagher JC, Rafferty KA, Balhorn KE. Dietary calcium and vitamin D intake in elderly women: effect on serum parathyroid hormone and vitamin D metabolites. American Journal of Clinical Nutrition 1998; 67: 342-8.

54 Sowers MR, Wallace RB, Hollis BW, Lemke JH. Parameters related to 25-OH-D levels in a population-based study of women. American Journal of Clinical Nutrition 1986; 43: $621-8$.

55 Ooms ME, Lips P, Roos JC, van der Vijgh WJ, Popp-Snijders C, Bezemer PD, et al. Vitamin D status and sex hormone binding globulin: determinants of bone turnover and bone mineral density in elderly women. Journal of Bone Mineral Research 1995; 10: 1177-84.

56 Sahota O, Masud T, San P, Hosking DJ. Vitamin D insufficiency increases bone turnover markers and enhances bone loss at the hip in patients with established vertebral osteoporosis. Clinical Endocrinology 1999; 51: 217-21.

57 Mezquita-Raya P, Munoz-Torres M, Luna JD, Luna V, Lopez-Rodriguez F, Torres-Vela E, et al. Relation between vitamin D insufficiency, bone density, and bone metabolism in healthy postmenopausal women. Journal of Bone Mineral Research 2002; 16: 1408-15.

58 Jesudason D, Need AG, Horowitz M, O'Loughlin PD, Morris HA, Nordin BE. Relationship between serum 25-hydroxyvitamin $\mathrm{D}$ and bone resorption markers in vitamin D insufficiency. Bone 2002; 31: 626-30. 